\title{
MARKETING TACTICS USED IN NETFLIX
}

\author{
Anakha E ${ }^{1}$, Dr. Sherin V George ${ }^{2}$, Akhil S.S ${ }^{3}$ \\ ${ }^{1}$ Post graduate student, Department of Psychology, Sree Sankaracharya University of Sanskrit, Kalady, India \\ ${ }^{2}$ Guest Lecturer, Department of Psychology, Sree Sankaracharya University of Sanskrit, Kalady, India \\ ${ }^{3}$ Post graduate student, Department of Psychology, Sree Sankaracharya University of Sanskrit, Kalady, India
}

\begin{abstract}
This study tried to analyze different marketing tactics used in most widely used online platform, Netflix. The problem of the study is stated as "Marketing tactics used in Netflix". Content Analysis method was used to find different strategies used in it. Different mode of marketing strategies was identified initially. Later they were analyzed separately in Netflix app. The study identified about 13 tactics used in Netflix app including colour psychology, font and writing style, mere exposure effect, that's not all technique, cliff hanger method, affect heuristic, scarcity heuristic, social proof marketing, usage of eye contact, personalization, reverse marketing, availability heuristic.
\end{abstract}

Keywords: Tactics, Netflix tactics, Marketing strategies, Colour psychology, Font style

\section{INTRODUCTION}

Netflix is an American media production and service company located in Los Gatos, California. It was founded by Reed Hastings and Marc Randolph in 1997 to enable users to watch a variety of TV shows, including documentaries, movies, TV series, etc. Netflix gave users unlimited viewing of content without watching a single advertisement. Marketing strategy is used by different companies to work with consumers. It is also used to educate customers about the company's features, specifications, and benefits. It essentially focuses on encouraging the target audience to purchase those specific products and services. Identifying the target audience is a basic and necessary step in choosing a marketing strategy. Providing appropriate demographic information help to choose the marketing plan that suits a particular business. Creating a hypothetical process of buying is also good to test audience. Once the buying behaviour of a target audience is understood, a more appropriate marketing strategy can be chosen. Many psychological strategies are used when marketing the Netflix app. There are some suggestions that marketing should be defined as applied business psychology. The essence of marketing is firmly rooted in the context of motivational needs. The concept assumes that the various efforts and goals of marketing professionals are aimed at achieving beneficial results for all participants involved in marketing communications. The main purpose of marketing is to play a beneficial role in helping consumers meet their needs, so as to ensure that the communication relationship between consumers and the organization works well. Perception is a series of mental processes that enable people to experience and conceptualize their environment through the active cognitive process of choice, organization, and interpretation. The original sensory information received by the sensory system allows vision, hearing, taste and touch to be understood based on a person's innate ability, previous learning and past experience.

\subsection{Aim}

To analyze the marketing tactics present in Netflix app

2.1 Materials

\section{METHOD}

2.1.1 Collection of materials regarding Netflix app in printed form

2.1.2 Paper

2.1.3 Pencil

\section{PROCEDURE}

Different mode of marketing strategies was identified initially. Later they were analyzed separately in Netflix app.

\section{RESULTS}

13 marketing tactics were identified and they are shown in tables

Table.1. Identified marketing tactics 
International Advanced Research Journal in Science, Engineering and Technology

Vol. 8, Issue 6, June 2021

DOI: $10.17148 / I A R J S E T .2021 .86102$

\begin{tabular}{|c|c|c|c|c|c|c|}
\hline Contents & Logo & Email & $\begin{array}{c}\text { Pop up } \\
\text { notifications }\end{array}$ & Advertisements & Hoarding & $\begin{array}{c}\text { YouTube } \\
\text { notification }\end{array}$ \\
\hline $\begin{array}{c}\text { Color } \\
\text { psychology }\end{array}$ & present & present & present & present & present & Present \\
\hline $\begin{array}{c}\text { Font and } \\
\text { writing style }\end{array}$ & present & present & present & present & present & Present \\
\hline $\begin{array}{c}\text { Mere exposure } \\
\text { effect }\end{array}$ & present & present & present & present & present & Present \\
\hline $\begin{array}{c}\text { That's not all } \\
\text { technique }\end{array}$ & nil & present & present & present & present & Present \\
\hline $\begin{array}{c}\text { Cliffhanger } \\
\text { method }\end{array}$ & nil & present & present & present & present & Present \\
\hline $\begin{array}{c}\text { Affect heuristic } \\
\text { present }\end{array}$ & present & present & present & present & Present \\
\hline $\begin{array}{c}\text { Scarcity } \\
\text { heuristic }\end{array}$ & nil & present & present & present & present & Present \\
\hline $\begin{array}{c}\text { Social proof } \\
\text { marketing }\end{array}$ & nil & nil & nil & present & present & Nil \\
\hline $\begin{array}{c}\text { Usage of eye } \\
\text { contact }\end{array}$ & nil & present & present & present & present & Present \\
\hline $\begin{array}{c}\text { Personalization } \\
\text { heuristic }\end{array}$ & nil & present & present & present & Nil & Present \\
\hline $\begin{array}{c}\text { Reverse } \\
\text { marketing }\end{array}$ & nil & present & present & present & Present & Present \\
\hline $\begin{array}{c}\text { Availability } \\
\text { heuresent }\end{array}$ & nil & nil & present & present & Present & Present \\
\hline
\end{tabular}

Table.2. The tactics analyzed in Netflix app

\begin{tabular}{|c|c|c|c|}
\hline $\begin{array}{c}\text { Color } \\
\text { psychology }\end{array}$ & Font and writing style & Mere exposure effect & That's not all technique \\
\hline $\begin{array}{lr}\text { Logo } & \text { of } \\
\text { Netflix } & \text { can } \\
\text { provide } & \\
\text { strong } & \\
\text { emotions } & \text { like } \\
\text { attention } & \text { and } \\
\text { power } & \end{array}$ & $\begin{array}{l}\text { Netflix has its own font } \\
\text { size= Netflix sans }=\text { gives } \\
\text { unique identity } \\
\text { Crown }=\text { serif style } \\
=\text { traditional, respectable } \\
\text { Luke Cage = Decorative } \\
\text { font = bold } \\
\text { Ozark = serif font = } \\
\text { money sign } \\
\text { Dear white people }=\text { Serif } \\
\text { bond }=\quad \text { challenging, } \\
\text { critical } \\
\text { Black mirror= proxima } \\
\text { nova bold }=\text { creepy feeling }\end{array}$ & $\begin{array}{l}\text { Notifications in you } \\
\text { tube, mobile phone, } \\
\text { pop up notifications, } \\
\text { hoardings, direct mails } \\
\text { and websites }\end{array}$ & $\begin{array}{l}30 \text { days trials } \\
\text { No annoying contacts } \\
\text { Download and go which saves } \\
\text { mobile data } \\
\text { Unlimited entertainment at low } \\
\text { prices } \\
3 \text { different packages are available }\end{array}$ \\
\hline
\end{tabular}


International Advanced Research Journal in Science, Engineering and Technology

Vol. 8, Issue 6, June 2021

DOI: $10.17148 /$ IARJSET.2021.86102

Table.3. The tactics analyzed in Netflix app

\begin{tabular}{|c|c|c|c|c|}
\hline $\begin{array}{l}\text { Cliffhanger } \\
\text { method }\end{array}$ & Affect heuristics & $\begin{array}{l}\text { Availability } \\
\text { heuristic }\end{array}$ & Scarcity heuristic & Social proof marketing \\
\hline $\begin{array}{l}\text { Contains mostly } \\
\text { series which } \\
\text { evokes anxiety }\end{array}$ & $\begin{array}{l}\text { Netflix provides a } \\
\text { positive } \\
\text { environment for } \\
\text { audience }\end{array}$ & $\begin{array}{l}\text { Repeated } \\
\text { advertisements }\end{array}$ & $\begin{array}{l}\text { Notification and } \\
\text { recommendations about } \\
\text { movies which is not } \\
\text { offered by others } \\
\text { No screenshots } \\
\text { Netflix productions }\end{array}$ & $\begin{array}{l}\text { Obama and michelle } \\
\text { produced contents for netflix }\end{array}$ \\
\hline
\end{tabular}

Table.4. The tactics analyzed in Netflix app

\begin{tabular}{|l|l|l|l|}
\hline Usage of eye contact & \multicolumn{1}{|c|}{ Personalization } & \multicolumn{1}{|c|}{$\begin{array}{c}\text { Free sample } \\
\text { marketing }\end{array}$} & Reverse marketing \\
\hline $\begin{array}{l}\text { Present in posters, } \\
\text { advertisements and } \\
\text { notifications }\end{array}$ & $\begin{array}{l}\text { Personalized recommendations } \\
\text { and offers through email, pop } \\
\text { up, you tube recommendations }\end{array}$ & Free trial for 30 days & $\begin{array}{l}\text { Television advertisements, } \\
\text { Magazine, hoardings, Online } \\
\text { media }\end{array}$ \\
\hline
\end{tabular}

\section{ANALYSES}

The purpose of the study was to analyze the marketing tactics used in growing trend app Netflix. Netflix is an American media-services provider and production company headquartered in Los Gatos, California, founded in 1997 by Reed Hastings and Marc Randolph in Scotts Valley, California.13 marketing tactics was identified initially and they were analyzed in Netflix app separately. The 13 tactics are color psychology, Font and writing style, Mere exposure effect, reciprocity or that's not all technique, cliffhanger method, Affect heuristics, availability heuristics, scarcity heuristic, social proof marketing, usage of eye contact, personalization, Free sample marketing and reversible marketing.Color plays an important role in how you view your brand. Theimportance of colorwill help you better attract and keep intouchwith ideal customers. Color psychology can be used to create strong andrecognizable brands. They think and act based onthe brand and how they interpret the information. The first analysis was conductedon the Netflix logo. Its logo is presented inredcapital letters ona black background. Red can attract attention. The meaning of red isrelatedtoexcitement, passion, danger, energy and action. In color psychology, red is the strongest color, so it canevoke the strongest emotions. Red can also bedangerous, so use color with caution. It is a very powerful and vibrant color that reflects our physical needs, whether itis an expressionof love or a symbolof fear,fear and survival. Red is also very exciting.A color can represent friendliness and strength, but it can also be demanding and aggressive depending on the context. Black is a popular color in the retail industry. In color psychology, the meaning of black isa symbol of mystery, power, elegance and sophistication. It is also a popular text colorbecause it is an easy-to-read color. The next tacticalassessmentisabout the font and writing style used in the Netflixapplication.He discovered that they had opened a new font called Netflix sans for their logo. They choose to create its own signs because it gives its own identity and uniqueness to the app which is attention seeking. The writing style andtypography were also evaluatedbetween the presentations of movies and TV series provided by the app. There are comedies, dramas, science fiction, epics, puzzles, and action movies, butthereare so many different shows to choose from, and theseshows need a unique appearance to fascinate the audience.Television series like The Crown, with a serif title gives it a "traditional and respectable appearance",just like the royal family itself. Luke Cage has a decorative font that requires bold letters on the cover of the comic. When we watch the show, we can see that the granite letters are verysuitable for the bulletproof heroesof Harlem. The Ozarks signature "Z"stands for banknotes. Here, they carry the message they are trying to convey. Dearwhitepeople", use the title, serif. The font praises the boldness of the show and the theme of challenging and criticizing social norms. The "BlackMirror" poster uses a special sansserif font to give the show a creepy feel. A modern font with a crack in the middle indicates that something inthe technology is broken. It also reveals the impact of a mere exposure effect. This means that merely repeating information will produce a sense of familiarity and a more positive attitude towards it. Netflix creates a sense of familiarity in us through several ways like notification in you tube and mobile phone, pop up notifications, hoardings, individual mails and advertisements. This enables the user to choose Netflix over other entertaining apps. That's not all is another technique gaining compliance in which requesters offer additional benefits to target people before they have decided whether to comply with or reject specific requests. Before deciding whether to allow or deny certain requests, people will give some people extra benefits. Netflixis using this strategy toprovide some discounts before subscribing, 


\section{International Advanced Research Journal in Science, Engineering and Technology}

Vol. 8, Issue 6, June 2021

\section{DOI: $10.17148 /$ IARJSET.2021.86102}

such as a 30-day free route. They offer about three subscription packages, ranging from 500 to 800 per month. Theymentioned that Netflix offers unlimited entertainment at low prices.

A cliffhanger method is a type of narrative or action device in which the ending is strangely abrupt, so that the protagonistsgetinto a difficult situation without offering a solution to the conflict. It can have more than two seasons. Netflixhas several of its own film and series releases. Itcausesa lot of concernamong users aboutsubscribing again in the future.The affect heuristic includes how we feel and then think. Netflixtakes advantageof this strategy by providing a positive environment to appealtoaudiences to think positively about the offers. By opening the application,individuals get an environment thatsuits theirpersonal preferences and choices. The availability heuristic is a mental shortcut that relies on immediate examples that come to mind to a particular person evaluating a particular topic, concept, method, or decision. This strategy is used by Netflix in a way that generates repeat ads and online media marketing. Users will have their first Netflix preference when it comes to entertainment. The scarcity heuristic is a mental shortcut that assigns a value to an item based on how easily it can be lost, especially to competitors. The scarcity heuristic isbased on the idea that the more difficult an item is to acquire, the more value that item has. This tactic is discussedwhen there is a Netflix release of series that cannot be found in any other application. Screenshotsare restricted. It provides notificationsof the latest movies and series not offered by others.People tend to imitate others. The actions of other people give us intel in any given situation. Socialproof is a key persuasion principle to make our decision-making easier. Socialproof is strongest when we arenotsure what to do or what to do. SocialProof can be analyzed on Netflix .Recently, Barrack Obama, the formerPresident of the United States, and his wife Michelle Obama unveiled their first projects in development with Netflix that willhave a greater impact on viewers as they are the mostfavorable personalities. Theuse of eye contact is another tactic that is analyzed. We cansee this technique in allNetflix posters and advertisements because it exertsaninfluenceon the userswhoattractsit. Personalization can also be seenon Netflix, here preferences for each individual customer areoffered and unique offers make their profit increase.Free sample marketing is another important tactic that is being discussed. Netflixoffers30-day routes to anyone new to Netflix.Reverse marketing is another technique that is being discussedon Netflix.This helps them to get customers to seek out business rather than seeking them. It can be seen mainly in magazines, television commercials, print media, and online.

\section{CONCLUSION}

It seems to have about 13 tactics identified in Netflix. Color psychology, font and writing style, mere exposure effect, personalization, heuristics, and cliffhanger method are major tactics used in Netflix for their growth and development

\section{References}

1. Baron, R. A., \& Branscombe, N. R.(2009). Social psychology (Mumbai University), 12/E (With cd). Pearson Education India.

2. Bassist, Elissa. “Addicted to Netflix: Teen-Soap-Opera Binge as Psychosis.” New York Magazine. New York Media, 27 Feb. 2013. Web. 14 June 2014

3. Chicago Tribune, 30 Nov 2011, "Netflix unveils download feature for offline binge-watching"

4. Diaz, Ann-Christine. "France's Version of Netflix Creates New Coffee Brand to Attract Viewers." Advertising Age. Crain Communications, 3 Dec. 2013. Web. 14 June 2014.

5. Edelhart, Marni. "Netflix Gives Millennials Easy Access to Media, Reaps Rewards with Subscribers and Emmys.” Pivot. The Tomorrow Project, n.d. Web. 14 June 2014.

6. Forbes 2017, "A closer look at Netflix"s content strategy

7. Kafka, Peter. "Surprise! You're Watching More TV Than Ever.” All Things Digital. Dow Jones and Company, 4 Dec. 2013. Web. 14 June 2014.

8. Mudhar, Raju. "The Netflix-ication of All Media." Toronto Star. Toronto Star Newspapers, 16 Oct. 2013. Web. 14 June 2014

9. Netflix Font. (n.d.). Retrieved from https://fontmeme.com/netflix-font/

10. Poggi, Jeanine. "TV Networks' Unusual Binge-Viewing Trials Have a Surprisingly Traditional Aim." Advertising Age. Crain Communications, 30 Oct. 2013. Web. 14 June 2014.

11. Szalai, George. "Netflix to Air New DreamWorks Animation Shows.” Hollywood Reporter. The Hollywood Reporter, 17 June 2013. Web. 14 June 2014.

12. Tao, Sophia. "More Students Start to Binge Watch over the Summer.” El Estoque. Monta Vista High School, 22 Aug. 2013. Web. 14 June 2014.

13. Waude, A. (2017, February 17). Compliance strategies: Common persuasion techniques. Retrieved from https://www.psychologistworld.com/behavior/compliance/strategies/overview

14. Wee, Valerie. Teen Media: Hollywood and the Youth Market in the Digital Age. Jefferson: McFarland, 2010. Print.

15. What Netflix's top 50 shows can teach us about Font psychology [Infographic]. (2020, June 14). Retrieved from https://venngage.com/blog/fontpsychology/

16. Wolff, Michael. "Netflix Plays Its “Cards' in a New Game Strategy.” USA Today 11 Feb. 2013: 1B. Print.

17. Ahmad A .I .Shajrawi; Nawab Ali Khan. "International Marketing in the Modern Era". International Research Journal on Advanced Science Hub, 2, Special Issue ICAET 11S, 2020, 16-19.

18. Chetan K; YogishS.N.. "Global Economy with comparative study of India and China in a pandemic situation". International Research Journal on Advanced Science Hub, 2, Special Issue ICAMET 10S, 2020, 1-5. doi: 10.47392/irjash.2020.190 